2014

\title{
Documentation of Caddo Vessels and Sherds in the Herrington Collection at Tyler Junior College, in Smith County, Texas
}

Timothy K. Perttula

Heritage Research Center, Stephen F. Austin State University

Bo Nelson

Robert Z. Selden Jr.

Heritage Research Center, Stephen F. Austin State University

Mark Walters

Follow this and additional works at: https://scholarworks.sfasu.edu/ita

Part of the American Material Culture Commons, Archaeological Anthropology Commons, Environmental Studies Commons, Other American Studies Commons, Other Arts and Humanities Commons, Other History of Art, Architecture, and Archaeology Commons, and the United States History Commons

Tell us how this article helped you.

This Article is brought to you for free and open access by the Center for Regional Heritage Research at SFA ScholarWorks. It has been accepted for inclusion in Index of Texas Archaeology: Open Access Gray Literature from the Lone Star State by an authorized editor of SFA ScholarWorks. For more information, please contact cdsscholarworks@sfasu.edu. 
Documentation of Caddo Vessels and Sherds in the Herrington Collection at Tyler Junior College, in Smith County, Texas

\section{Creative Commons License}

\section{(c) (1) \&}

This work is licensed under a Creative Commons Attribution-NonCommercial 4.0 International License 


\section{Documentation of Caddo Vessels and Sherds in the Herrington Collection at Tyler Junior College, in Smith County, Texas}

Timothy K. Perttula, Bo Nelson, Robert Z. Selden Jr., and Mark Walters

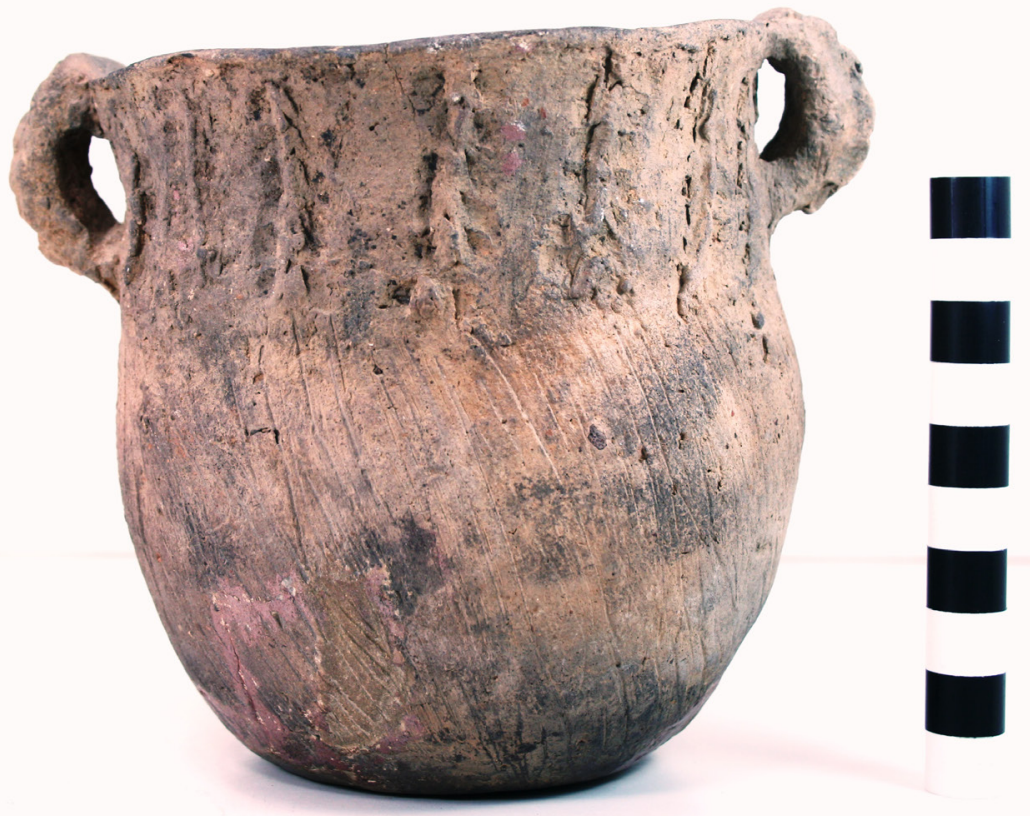

Special Publication No. 34

Friends of Northeast Texas Archaeology (Austin and Pittsburg) 
Distribution, Bo Nelson, 344 CR 4154

Pittsburg, Texas 75686

RBoNelson@aol.com

\section{Cover art:}

cf. Killough Pinched jar

Copyright (C) 2014, Friends of Northeast Texas Archaeology (Austin and Pittsburg) 


\section{Table of Contents}

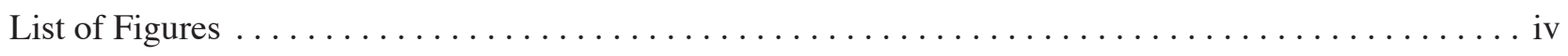

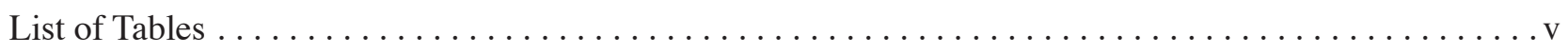

Acknowledgments $\ldots \ldots \ldots \ldots \ldots \ldots \ldots \ldots \ldots \ldots \ldots \ldots \ldots \ldots \ldots \ldots \ldots \ldots \ldots \ldots \ldots \ldots \ldots \ldots \ldots$

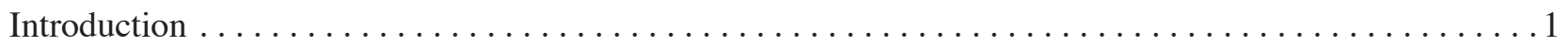

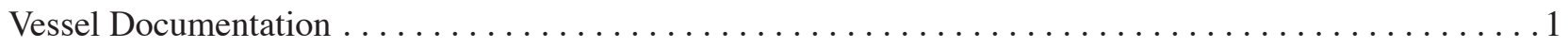

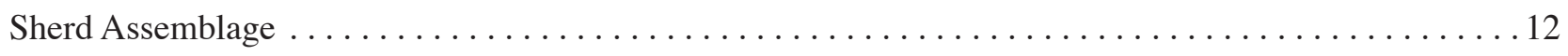

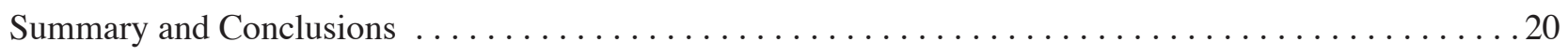

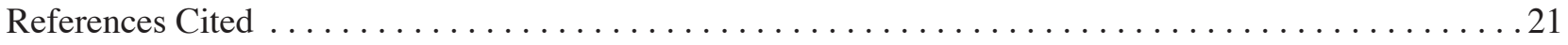




\section{List of Figures}

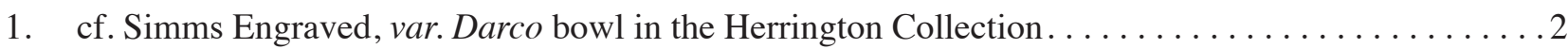

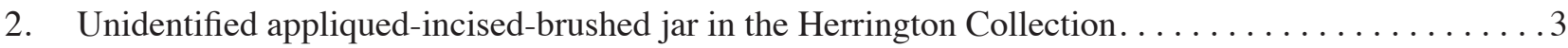

3. Bullard Brushed jar in the Herrington Collection $\ldots \ldots \ldots \ldots \ldots \ldots \ldots \ldots \ldots \ldots \ldots \ldots \ldots$

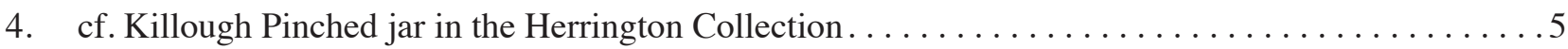

5. $\quad$ cf. Killough Pinched jar in the Herrington Collection $\ldots \ldots \ldots \ldots \ldots \ldots \ldots \ldots \ldots \ldots \ldots$

6. Simms Engraved carinated bowl in the Herrington Collection $\ldots \ldots \ldots \ldots \ldots \ldots \ldots \ldots \ldots \ldots$

7. Unidentified brushed-incised jar in the Herrington Collection $\ldots \ldots \ldots \ldots \ldots \ldots \ldots \ldots \ldots$

8. Harleton Appliqued jar in the Herrington Collection $\ldots \ldots \ldots \ldots \ldots \ldots \ldots \ldots \ldots \ldots \ldots$

9. La Rue Neck Banded jar rim and body sherds in the Herrington Collection . . . . . . . . . . 10

10. Miscellaneous decorated sherds: a, incised body; b, engraved body sherd;

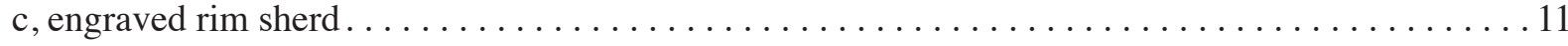

11. Incised and incised-punctated decorative elements: a-d, incised-punctated body sherds;

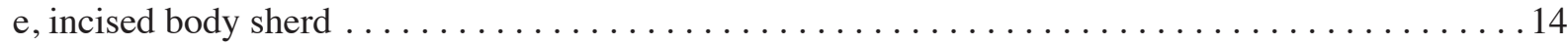

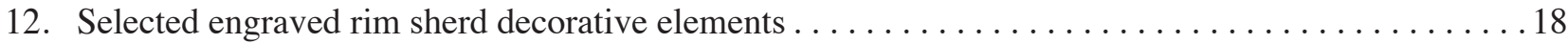

13. Engraved and trailed body sherd decorative elements: a-n, engraved body;

o, trailed body sherd. . . . . . . . . . . . . . . . . . . . . . . . . . . . . . . . . . . 19 


\section{List of Tables}

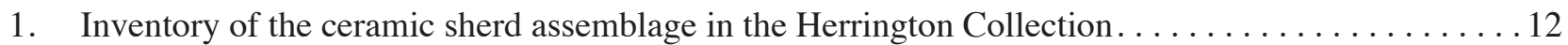

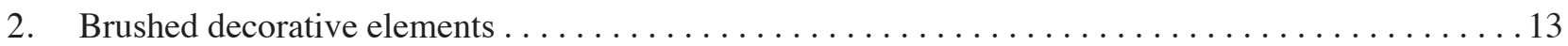

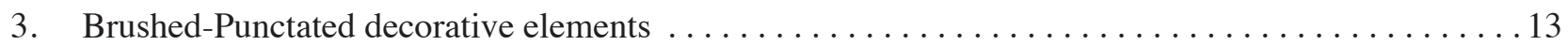

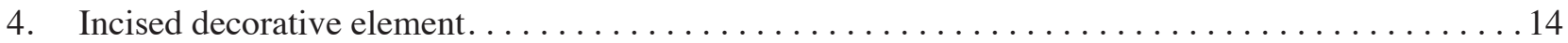

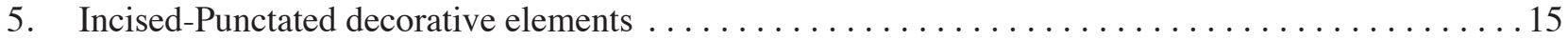

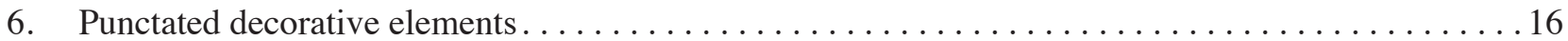

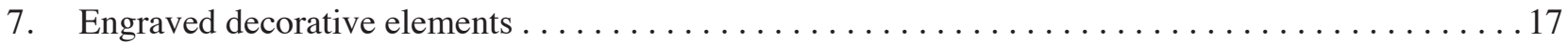




\section{Acknowledgements}

We thank Robin Insalaco and other staff at Tyler Junior College for providing permission to document the ancestral Caddo artifact collections held by Tyler Junior College, as well as access to work on the collections in the Library on campus. Lance Trask prepared Figures 10-13 for the report. 


\section{Introduction}

This report puts on record the collection of ancestral Caddo vessels and sherds held by Tyler Junior College (TJC) in Tyler, Texas. This collection was donated by Al Herrington to TJC in 2012. The vessels and sherds in this collection have been documented following the methods employed by the Friends of Northeast Texas Archaeology and Archeological \& Environmental Consultants, LLC on a number of ancestral Caddo ceramic collections from East Texas archaeological sites (e.g., Perttula 2011, 2013, 2014; Perttula and Nelson 2013; Perttula and Thacker 2014; Perttula et al. 2007, 2009a, 2009b, 2010a, 2010b, 2010c, 2012a, 2012b, 2012c, 2013, 2014). The provenance of the Caddo vessels and sherd assemblage is not known with certainty, but (as we discuss in the Summary and Conclusions section of the report) the decorative styles of the vessels and sherds indicate they are from East Texas Caddo sites, most likely from sites in the Neches and Sabine river basins.

\section{Vessel Documentation}

There are nine ancestral Caddo ceramic vessels in the TJC collections. Two are engraved fine ware vessels, and the remaining seven are utility ware jars. They are tempered with grog (crushed sherds) $(n=6)$, grog and burned bone $(n=1)$, and burned bone $(n=2)$

SITE NAME OR SITE NUMBER: Herrington Collection

VESSEL NO.: 1

VESSEL FORM: Bowl

NON-PLASTICS AND PASTE: grog and bone

RIM AND LIP FORM: Inverted rim and rounded lip

CORE COLOR: B (fired and cooled in a reducing environment)

INTERIOR SURFACE COLOR: very dark grayish-brown

EXTERIOR SURFACE COLOR: dark grayish-brown; fire clouds on the body

WALL THICKNESS (IN MM): rim, $6.2 \mathrm{~mm}$

INTERIOR SURFACE TREATMENT: smoothed

EXTERIOR SURFACE TREATMENT: burnished

HEIGHT (IN CM): 11.5; rim height is $3.5 \mathrm{~cm}$

ORIFICE DIAMETER (IN CM): 21.4

DIAMETER AT BOTTOM OF RIM OR NECK (IN CM): 18.0

BASE DIAMETER (IN CM) AND SHAPE OF BASE: 7.2; circular and flat 
ESTIMATED VOLUME (IN LITERS): 1.0

DECORATION (INCLUDING MOTIF AND ELEMENTS WHEN APPARENT): The rim has a panel marked by three horizontal engraved lines. The upper and lower horizontal lines have diagonal tick marks that point towards the central engraved line in the panel (Figure 1).

PIGMENT USE AND LOCATION ON VESSEL: white pigment in engraved lines

TYPE AND VARIETY (IF KNOWN): cf. Simms Engraved, var. Darco

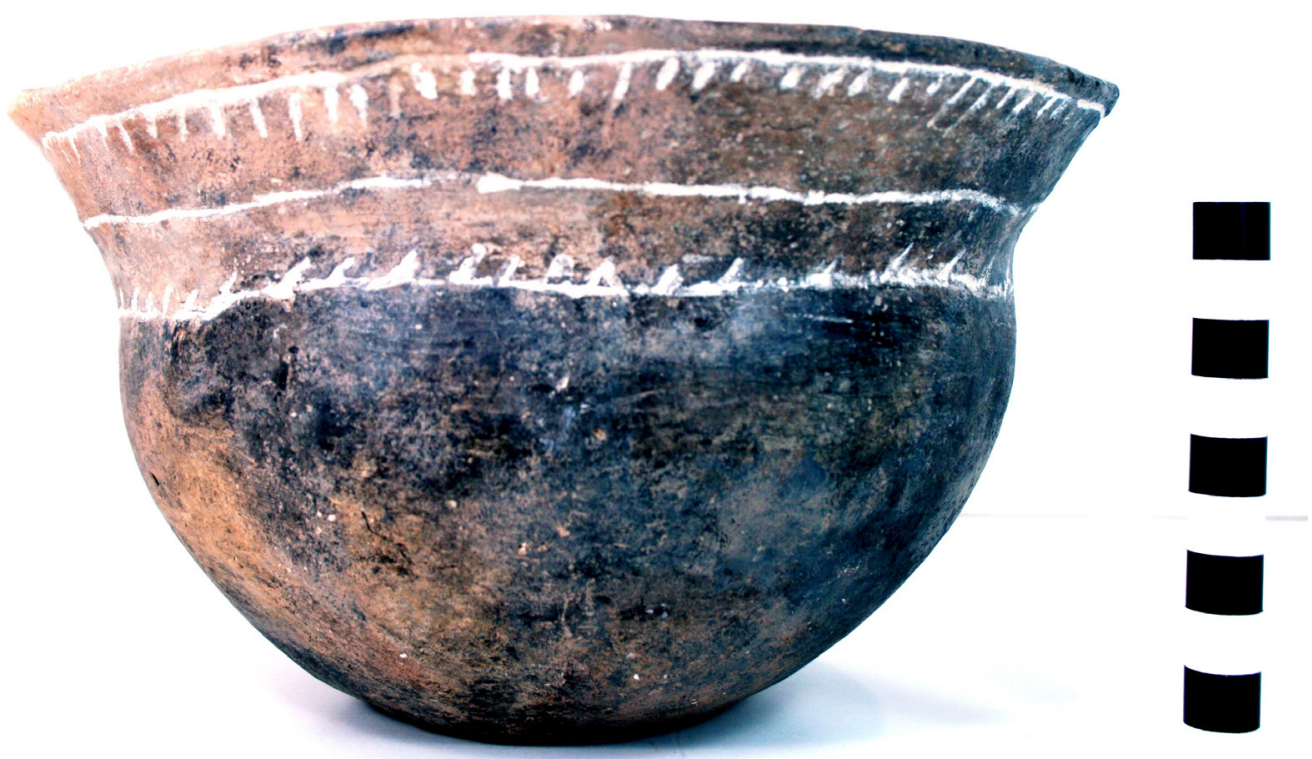

Figure 1. cf. Simms Engraved, var. Darco bowl in the Herrington Collection. 
SITE NAME OR SITE NUMBER: Herrington Collection

VESSEL NO.: 2

VESSEL FORM: Jar

NON-PLASTICS AND PASTE: grog

RIM AND LIP FORM: Everted rim with a rounded and exterior folded lip

CORE COLOR: $\mathrm{G}$ (fired in a reducing environment and cooled in the open air)

INTERIOR SURFACE COLOR: black

EXTERIOR SURFACE COLOR: dark yellowish-brown

WALL THICKNESS (IN MM): $\operatorname{rim}, 7.5 \mathrm{~mm}$

INTERIOR SURFACE TREATMENT: smoothed

EXTERIOR SURFACE TREATMENT: smoothed on the vessel body

HEIGHT (IN CM): 29.8

ORIFICE DIAMETER (IN CM): 27.5

DIAMETER AT BOTTOM OF RIM OR NECK

(IN CM): 23.6

BASE DIAMETER (IN CM) AND SHAPE

OF BASE: 10.0; circular and flat

ESTIMATED VOLUME (IN LITERS): 10.7

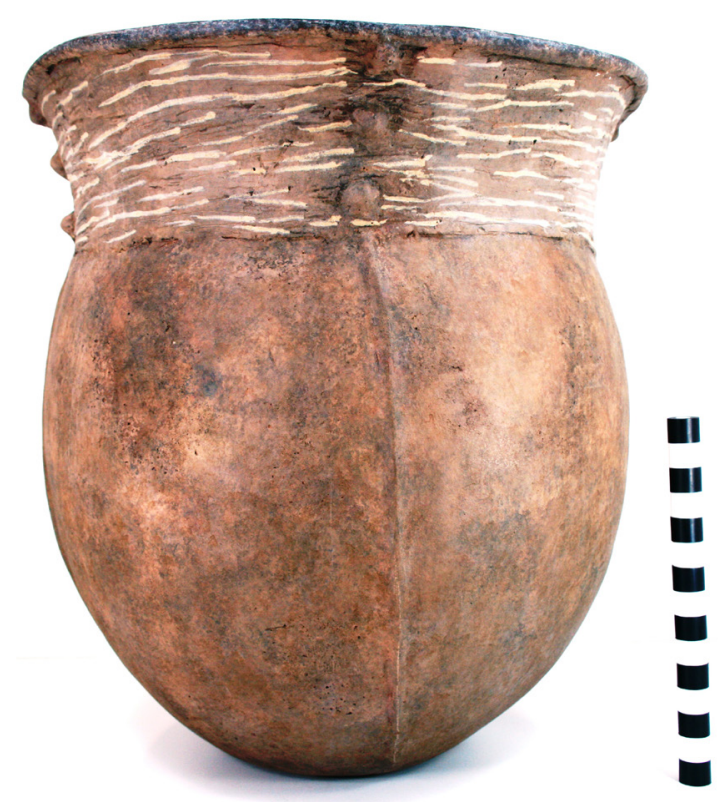

Figure 2. Unidentified appliqued-incised-brushed jar in the Herrington Collection.

DECORATION (INCLUDING MOTIF AND ELEMENTS WHEN APPARENT): The rim has four vertical rows of three appliqued nodes, and there are incised-brushed lines and marks between the appliqued nodes. The vessel body has four vertical appliqued ridges that extend from the rim-body juncture to near the base. These appliqued ridges are aligned with the vertical rows of appliqued nodes on the vessel rim (Figure 2).

PIGMENT USE AND LOCATION ON VESSEL: None

TYPE AND VARIETY (IF KNOWN): Unidentified utility ware 
SITE NAME OR SITE NUMBER: Herrington Collection

VESSEL NO.: 3

VESSEL FORM: Jar

NON-PLASTICS AND PASTE: grog

RIM AND LIP FORM: Everted rim and a rounded lip

CORE COLOR: B (fired and cooled in a reducing environment)

INTERIOR SURFACE COLOR: dark gray

EXTERIOR SURFACE COLOR: dark brown; fire clouds on the rim, body, and base

WALL THICKNESS (IN MM): rim, $7.9 \mathrm{~mm}$

INTERIOR SURFACE TREATMENT: smoothed

EXTERIOR SURFACE TREATMENT: none

HEIGHT (IN CM): 26.6

ORIFICE DIAMETER (IN CM): 24.3

DIAMETER AT BOTTOM OF RIM OR NECK (IN CM): 20.5

BASE DIAMETER (IN CM) AND SHAPE OF BASE: 9.0; circular and flat

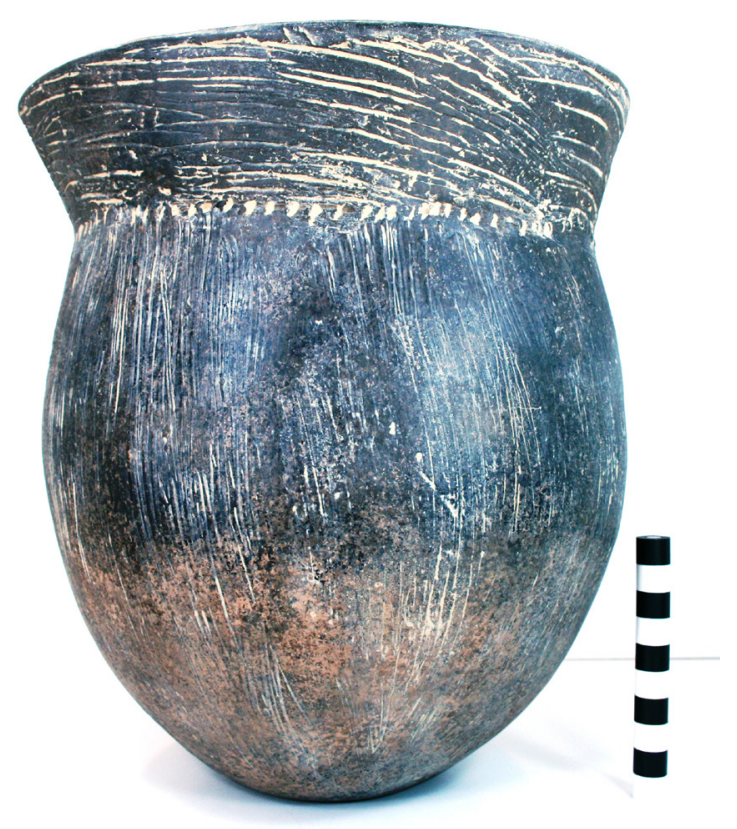

Figure 3. Bullard Brushed jar in the

ESTIMATED VOLUME (IN LITERS): 8.4 Herrington Collection.

DECORATION (INCLUDING MOTIF AND ELEMENTS WHEN APPARENT): The vessel rim has horizontal brushing marks as well as a row of tool punctations at the rim-body juncture. The vessel body has vertical brushing marks that extend to within $30 \mathrm{~mm}$ of the base (Figure 3 ).

PIGMENT USE AND LOCATION ON VESSEL: none

TYPE AND VARIETY (IF KNOWN): Bullard Brushed 
SITE NAME OR SITE NUMBER: Herrington Collection

VESSEL NO.: 4

VESSEL FORM: Jar

NON-PLASTICS AND PASTE: bone

RIM AND LIP FORM: Direct rim and rounded lip

CORE COLOR: E (incompletely oxidized during firing)

INTERIOR SURFACE COLOR: yellowish-brown

EXTERIOR SURFACE COLOR: reddish-brown; fire clouds on the body and base

WALL THICKNESS (IN MM): rim, $4.4 \mathrm{~mm}$; body, $5.6 \mathrm{~mm}$; base, $6.5 \mathrm{~mm}$

INTERIOR SURFACE TREATMENT: smoothed

EXTERIOR SURFACE TREATMENT: none

HEIGHT (IN CM): 6.6

ORIFICE DIAMETER (IN CM): 9.6

DIAMETER AT BOTTOM OF RIM

OR NECK (IN CM): 9.3

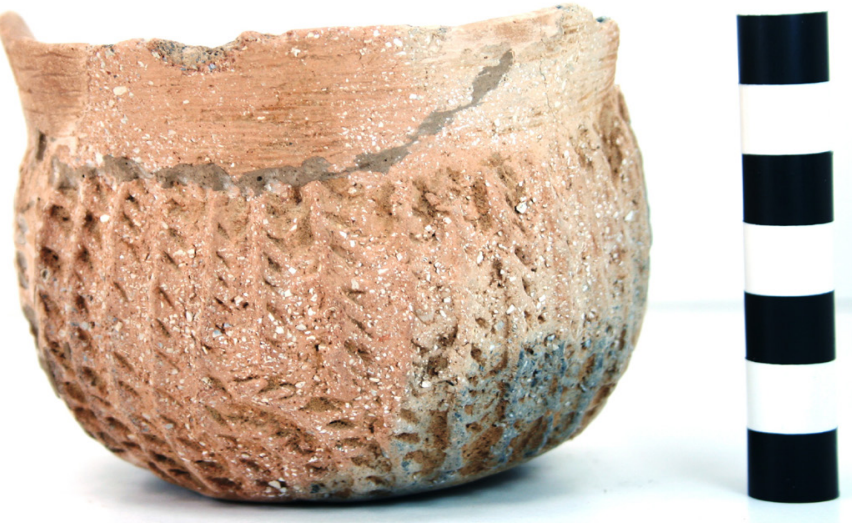

Figure 4. cf. Killough Pinched jar in the Herrington Collection.

BASE DIAMETER (IN CM) AND SHAPE OF BASE: 6.0; circular and flat

ESTIMATED VOLUME (IN LITERS): 0.4

DECORATION (INCLUDING MOTIF AND ELEMENTS WHEN APPARENT): The rim has horizontal brushing marks. The vessel body has a continuous series of vertical pinched ridges that extend from the rimbody juncture to the vessel base (Figure 4).

PIGMENT USE AND LOCATION ON VESSEL: none

TYPE AND VARIETY (IF KNOWN): cf. Killough Pinched 
SITE NAME OR SITE NUMBER: Herrington Collection

VEESEL NO.: 5

VESSEL FORM: Jar with two strap handles $(3.7 \times 2.1 \mathrm{~cm}$ in length and width)

NON-PLASTICS AND PASTE: grog

RIM AND LIP FORM: Everted rim and a rounded lip

CORE COLOR: F (fired in a reducing environment and cooled in the open air)

INTERIOR SURFACE COLOR: dark yellowish-brown; fire clouds on the rim and body

EXTERIOR SURFACE COLOR: dark yellowishbrown; fire clouds on the rim and body

WALL THICKNESS (IN MM): rim, 5.7 mm

INTERIOR SURFACE TREATMENT: smoothed

EXTERIOR SURFACE TREATMENT: none

HEIGHT (IN CM): 11.5

ORIFICE DIAMETER (IN CM): 11.5

DIAMETER AT BOTTOM OF RIM OR NECK (IN CM): 10.3

BASE DIAMETER (IN CM) AND SHAPE OF

BASE: 7.0; circular and flat

Figure 5. cf. Killough Pinched jar in the Herrington Collection.

ESTIMATED VOLUME (IN LITERS): 0.8

DECORATION (INCLUDING MOTIF AND ELEMENTS WHEN APPARENT): The rim has a series of vertical pinched ridges. The vessel body has vertical brushing marks that extend from the rim-body juncture to within $15 \mathrm{~mm}$ of the base (Figure 5). The strap handles are decorated with two vertical pinched ridges.

PIGMENT USE AND LOCATION ON VESSEL: none

TYPE AND VARIETY (IF KNOWN): cf. Killough Pinched 
SITE NAME OR SITE NUMBER: Herrington Collection

VESSEL NO.: 6

VESSEL FORM: Carinated bowl

NON-PLASTICS AND PASTE: grog

RIM AND LIP FORM: Inverted rim and rounded lip

CORE COLOR: F (fired in a reducing environment and cooled in the open air)

INTERIOR SURFACE COLOR: reddish-brown; fire clouds on the base

EXTERIOR SURFACE COLOR: reddish-brown; fire clouds on the body and base

WALL THICKNESS (IN MM): rim, $5.6 \mathrm{~mm}$

INTERIOR SURFACE TREATMENT:

smoothed

EXTERIOR SURFACE TREATMENT:

burnished

HEIGHT (IN CM): 10.5

ORIFICE DIAMETER (IN CM): 19.8

DIAMETER AT BOTTOM OF RIM

OR NECK (IN CM): 21.0

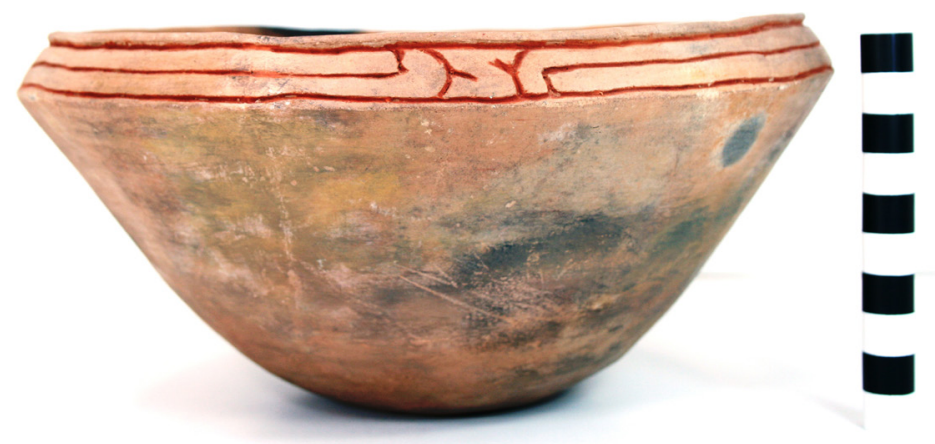

Figure 6. Simms Engraved carinated bowl in the Herrington Collection.

BASE DIAMETER (IN CM) AND SHAPE OF BASE: 6.8; circular and flat

ESTIMATED VOLUME (IN LITERS): 1.2

DECORATION (INCLUDING MOTIF AND ELEMENTS WHEN APPARENT): The rim panel has a horizontal engraved scroll repeated four times around the vessel. The scrolls are divided by vertical brackets with diagonal tick marks on either side of the bracket (Figure 6).

PIGMENT USE AND LOCATION ON VESSEL: red pigment in engraved lines

TYPE AND VARIETY (IF KNOWN): Simms Engraved 
SITE NAME OR SITE NUMBER: Herrington Collection

VESSEL NO: 7

VESSEL FORM: Jar with a short rim

NON-PLASTICS AND PASTE: bone

RIM AND LIP FORM: Everted rim and a rounded, exterior folded lip

CORE COLOR: B (fired and cooled in a reducing environment)

INTERIOR SURFACE COLOR: black

EXTERIOR SURFACE COLOR: very dark grayish-brown; fire clouds and organic residue on the vessel body

WALL THICKNESS (IN MM): rim, 7.1 mm

INTERIOR SURFACE TREATMENT: smoothed

EXTERIOR SURFACE TREATMENT: none

HEIGHT (IN CM): 13.3

ORIFICE DIAMETER (IN CM): 12.0

DIAMETER AT BOTTOM OF RIM OR NECK (IN CM): 10.4

BASE DIAMETER (IN CM) AND SHAPE OF

BASE: 6.9; circular and flat

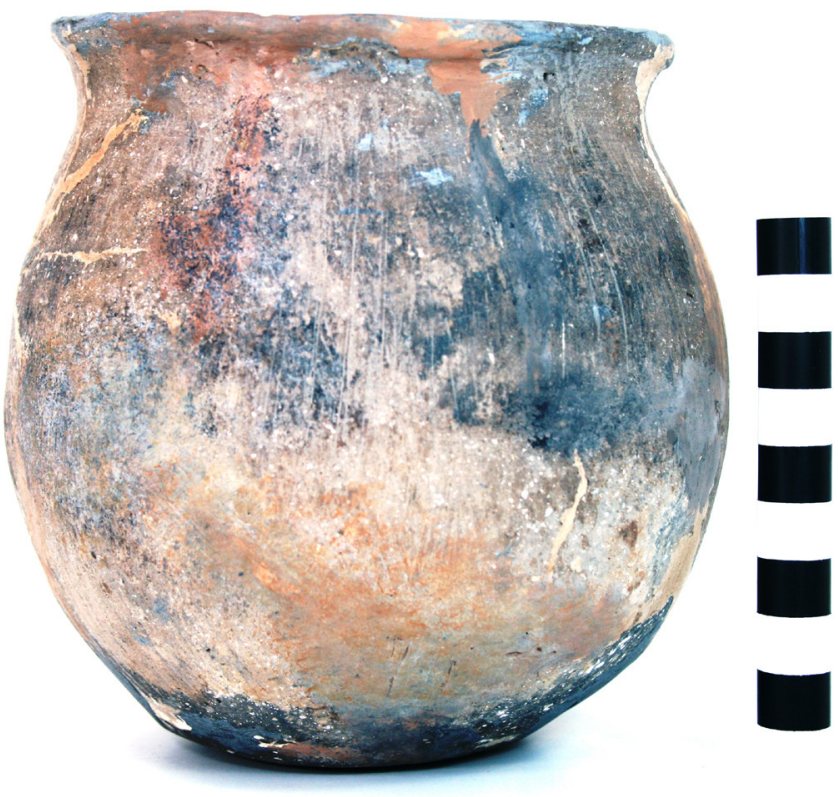

Figure 7. Unidentified brushed-incised jar in the Herrington Collection.

ESTIMATED VOLUME (IN LITERS): 1.0

DECORATION (INCLUDING MOTIF AND ELEMENTS WHEN APPARENT): The rim is plain, but the vessel body has vertical brushed-incised marks and lines that extend to the vessel base (Figure 7).

PIGMENT USE AND LOCATION ON VESSEL: none

TYPE AND VARIETY (IF KNOWN): Unidentified utility ware 
SITE NAME OR SITE NUMBER: Herrington Collection

VESSEL NO: 10

VESSEL FORM: Jar

NON-PLASTICS AND PASTE: grog

RIM AND LIP FORM: Everted rim and rounded lip

CORE COLOR: B (fired and cooled in a reducing environment)

INTERIOR SURFACE COLOR: black

EXTERIOR SURFACE COLOR: black; fire clouds on the base; organic residue on the vessel rim and body

WALL THICKNESS (IN MM): rim, $6.5 \mathrm{~mm}$

INTERIOR SURFACE TREATMENT: smoothed

EXTERIOR SURFACE TREATMENT: none

HEIGHT (IN CM): 14.2

ORIFICE DIAMETER (IN CM): 13.0

DIAMETER AT BOTTOM OF RIM OR NECK (IN CM): 11.3

BASE DIAMETER (IN CM) AND SHAPE OF

BASE: 5.9; circular and flat

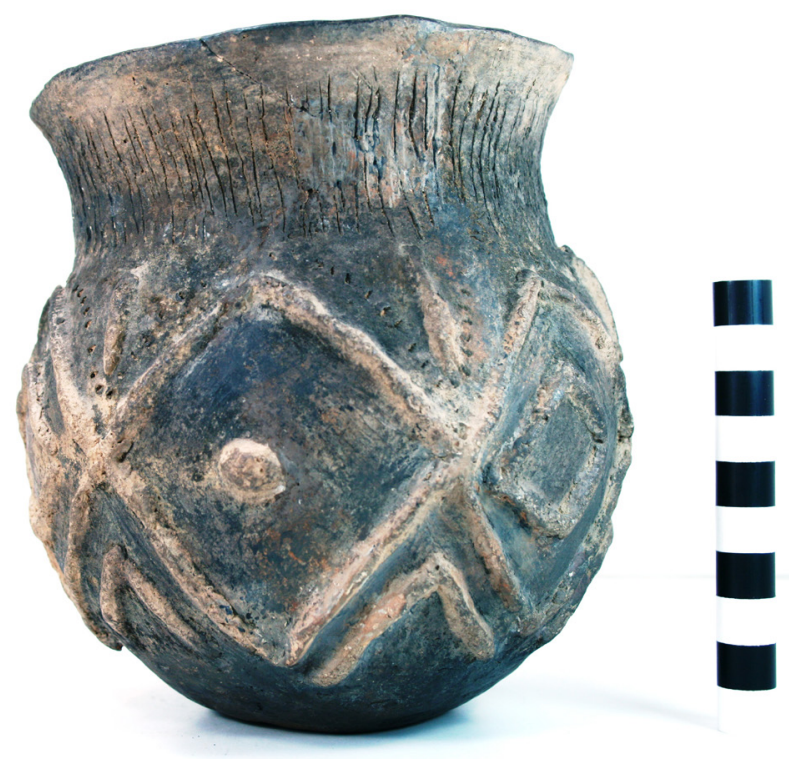

Figure 8. Harleton Appliqued jar in the Herrington Collection.

\section{ESTIMATED VOLUME (IN LITERS): 1.1}

DECORATION (INCLUDING MOTIF AND ELEMENTS WHEN APPARENT): The rim is decorated with a continuous series of vertical incised lines. The upper part of the body has short vertical appliqued ridges above a slanting row of tool punctates and six equally-spaced diamond-shaped appliqued ridge elements (Figure 8). Three of the appliqued diamonds have a central appliqued node, while the other three have a smaller central appliqued diamond. Between each of the appliqued diamond elements, and above the vessel base, are small appliqued ridge triangle elements (Figure 8).

PIGMENT USE AND LOCATION ON VESSEL: none

TYPE AND VARIETY (IF KNOWN): Harleton Appliqued 
SITE NAME OR SITE NUMBER: Herrington Collection

VESSEL NO.: No number (“Caddo Broken Pot” on TJC Herrington Inventory)

VESSEL FORM: Jar with a short rim

NON-PLASTICS AND PASTE: grog

RIM AND LIP FORM: Everted rim and a rounded-exterior folded lip

CORE COLOR: F (fired in a reducing environment and cooled in the open air)

INTERIOR SURFACE COLOR: dark yellowish-brown; fire clouds on the rim and body

EXTERIOR SURFACE COLOR: dark yellowish-brown; fire clouds on the rim and body

WALL THICKNESS (IN MM): rim, $6.2 \mathrm{~mm}$; body, $6.7 \mathrm{~mm}$; base, $11.5 \mathrm{~mm}$

INTERIOR SURFACE TREATMENT:

smoothed

EXTERIOR SURFACE TREATMENT: none

HEIGHT (IN CM): N/A

ORIFICE DIAMETER (IN CM): 24.0

DIAMETER AT BOTTOM OF RIM OR

NECK (IN CM): 23.4

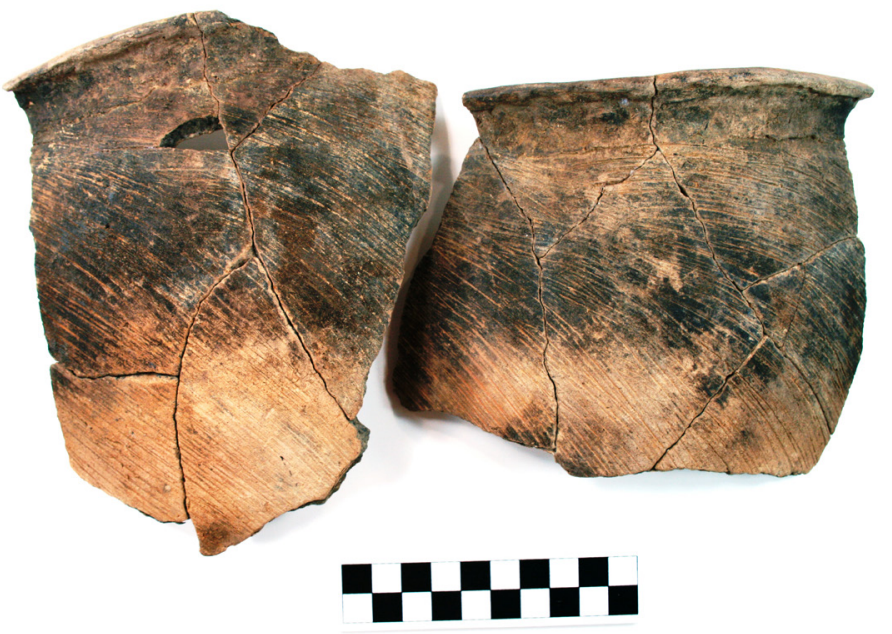

Figure 9. La Rue Neck Banded jar rim and body sherds in the Herrington Collection.

BASE DIAMETER (IN CM) AND SHAPE OF BASE: 9.5; circular and flat

ESTIMATED VOLUME (IN LITERS): N/A

DECORATION (INCLUDING MOTIF AND ELEMENTS WHEN APPARENT): The rim has a single neck banded row/coil (Figure 9). The vessel body has vertical and diagonal brushing marks that extend from the rim-body juncture to the vessel base.

PIGMENT USE AND LOCATION ON VESSEL: none

TYPE AND VARIETY (IF KNOWN): La Rue Neck Banded 
There are also eight miscellaneous sherds in the collection with the broken La Rue Neck Banded jar. They include one grog-tempered parallel brushed body sherd; four body sherds with parallel incised lines (three grog- and one bone-tempered); one grog-tempered body sherd with a horizontal and vertical incised decorative element (Figure 10a); and two engraved sherds. One grog-tempered body sherd has closely-spaced sets of opposed engraved lines and an embedded triangle element (Figure 10b), and the other is a grog-tempered rim sherd from a Poynor Engraved carinated bowl (see Perttula 2011:Figure 6-65) with a series of excised pendant triangles (Figure 10c). The rim has a direct profile with a roundedexterior folded lip; the orifice diameter is $22.0 \mathrm{~cm}$.

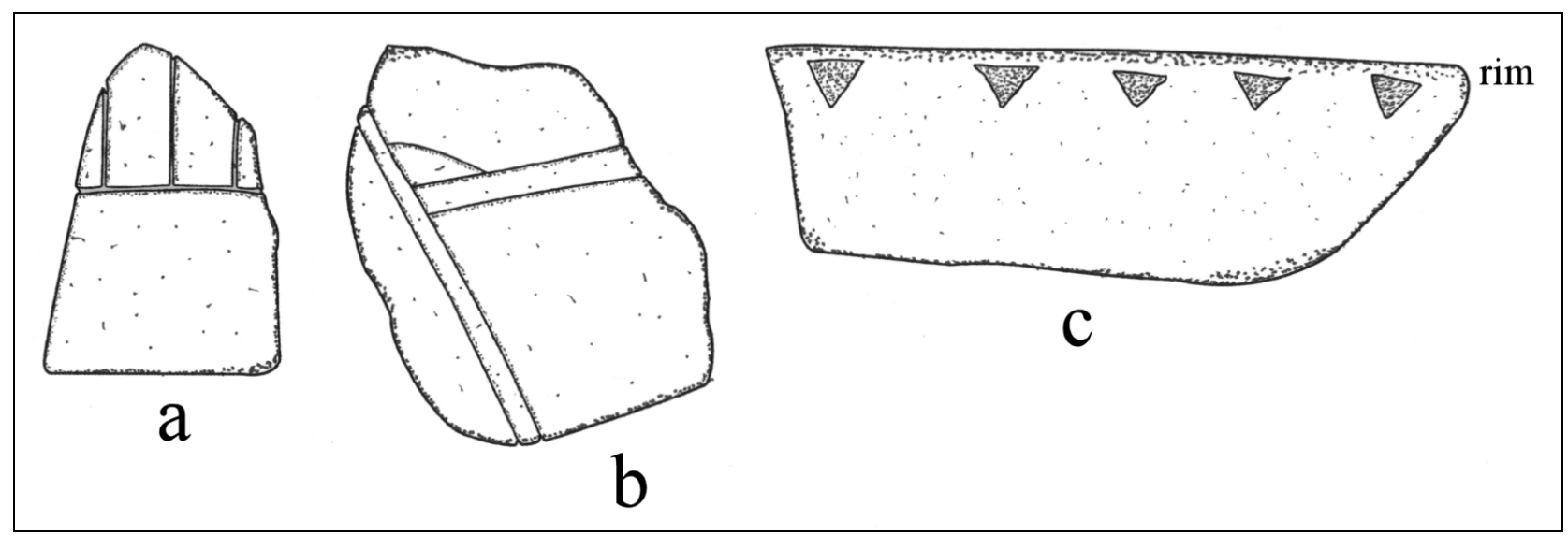

Figure 10. Miscellaneous decorated sherds: a, incised body; b, engraved body sherd; c, engraved rim sherd. 


\section{Sherd Assemblage}

The sherd assemblage in the Herrington Collection at the TJC is comprised of 663 rim and body sherds. Almost 98 percent of the sherds are from grog-tempered vessels, and the remainder are bonetempered. The very high density of grog-tempered vessels points towards an upper Neches River basin source for the sherd assemblage (see Perttula 2011).

There are 375 plain sherds and 288 sherds with decorative elements (Table 1). The plain to decorated sherd ratio for the assemblage is 1.30, consistent with post-A.D. 1300-1400 ancestral Caddo domestic ceramic assemblage in certain parts of East Texas, such as in Caddo sites in the Neches and Sabine River basins.

Table 1. Inventory of the ceramic sherd assemblage in the Herrington Collection.

\begin{tabular}{lcc}
\hline Decorative element & Grog-tempered & Bone-tempered \\
\hline Plain & 364 & 11 \\
& & - \\
Appliqued & 1 & 2 \\
Brushed & 82 & - \\
Brushed-Punctated & 8 & 1 \\
Engraved & 64 & 1 \\
Incised & 94 & - \\
Incised-Punctated & 8 & - \\
Neck Banded & 2 & - \\
Pinched & 1 & - \\
Punctated, circular & 4 & - \\
Punctated, fingernail & 8 & - \\
Punctated, tool & 10 & - \\
Red-slipped & 1 & 15 \\
Trailed & 1 & - \\
\hline Totals & 648 & - \\
\hline
\end{tabular}

The ceramic sherds are from a variety of plain and decorated vessels, including bowls, carinated bowls, jars, and bottles. The 49 rim sherds in the collection indicate that two vessels (4 percent) have notable rim peaks and another has a scalloped rim. Approximately 30 percent of the rims are from plain vessels, including bowls and bottles. Overall, almost 84 percent of the rims are from vessels with vertical or straight walls; the remainder have everted or outflaring rims (these are from jars). The vessel lips are rounded (71 percent), rounded and exterior folded ( 8 percent), and flat (20 percent).

Utility wares in the TJC sherd collection comprise 77 percent $(n=221)$ of the decorated sherds. These are sherds with wet paste decorative elements; i.e., the vessels were decorated (with appliqued, brushed, incised, neck banded, pinched, and punctated elements) while the vessels were still wet and not fired. The most common utility ware decorations in the TJC assemblage are various incised (43 percent), brushed (38 percent), and punctated (10 percent) elements (see Table 1). 
The one appliqued body sherd has curvilinear appliqued ridge decorative elements. The brushed body sherds (Table 2) are likely from Bullard Brushed jars (see Suhm and Jelks 1962:21 and Plate 11) with brushed rims and bodies; the brushing marks are primarily oriented vertically on the vessel rim and body.

Table 2. Brushed decorative elements.

\begin{tabular}{lcc}
\hline Decorative element & Rim & Body \\
\hline overlapping brushed marks & - & 28 \\
parallel brushed marks & - & 55 \\
vertical brushed marks & 1 & - \\
\hline Totals & 1 & 83 \\
\hline
\end{tabular}

The brushed-punctated sherds are from the bodies of utility ware jars (Table 3). These are likely also from Bullard Brushed jars with vertical or opposed brushed bodies that have rows of punctates (fingernail and tool) pushed through the brushing, or from Bullard Brushed or Maydelle Incised jars with a tool punctated row at the rim-body juncture and brushed bodies (see Suhm and Jelks 1962:Plates 11 and 52).

Table 3. Brushed-Punctated decorative elements.

\begin{tabular}{lcc}
\hline Decorative element & Rim & Body \\
\hline $\begin{array}{l}\text { opposed brushed with tool punctated row through the brushing } \\
\text { parallel brushed and adjacent tool punctated row } \\
\text { parallel brushed with fingernail punctates pushed through } \\
\begin{array}{l}\text { the brushing } \\
\text { parallel brushed with tool punctates pushed through the brushing }\end{array}\end{array}$ & - & 1 \\
\hline Totals & - & 2 \\
\hline
\end{tabular}

In addition to parallel and straight incised lines as decorative elements on utility wares in this sherd assemblage, there are also cross-hatched, curvilinear, diagonal, and horizontal incised lines (Table 4). These various decorative elements occur on both Dunkin Incised and Maydelle Incised vessels (see Suhm and Jelks 1962: Plates 19 and 52). Other incised sherds have horizontal, diagonal, and vertical lines (Figure 11e) that are likely part of triangular and curvilinear zones filled with incised lines. 
Table 4. Incised decorative elements.

\begin{tabular}{lcr}
\hline Decorative element & Rim & Body \\
\hline cross-hatched lines & 1 & 21 \\
curvilinear lines & - & 5 \\
diagonal lines & 3 & - \\
horizontal line & 1 & - \\
horizontal, diagonal, and vertical lines & - & 1 \\
parallel lines & - & 42 \\
scroll lines & - & 6 \\
single straight line & - & 15 \\
\hline Totals & 5 & 90 \\
\hline
\end{tabular}

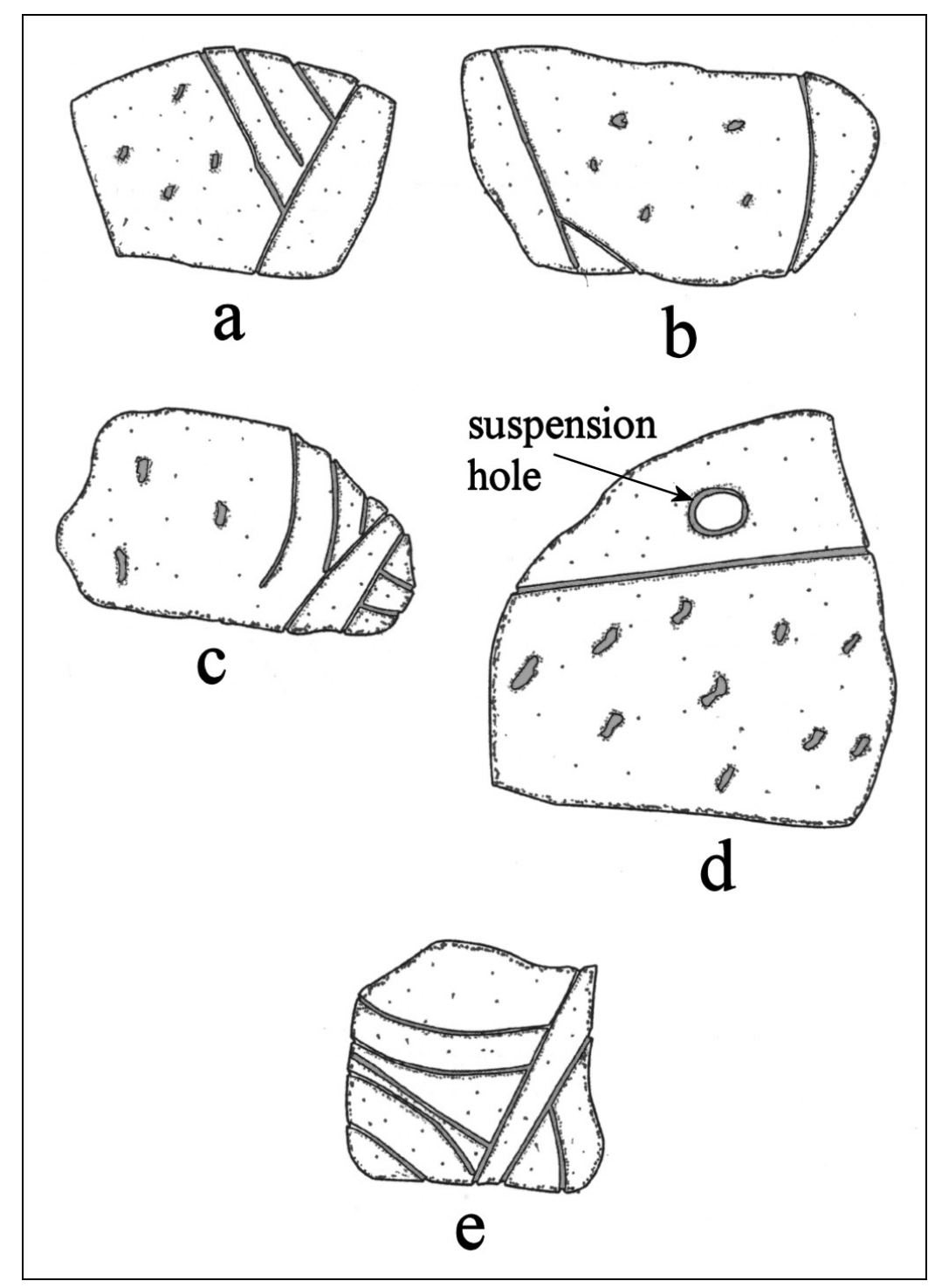

Figure 11. Incised and incised-punctated decorative elements: a-d, incised-punctated body sherds; e, incised body sherd. 
Several incised sherds in the assemblage (see Table 4) have portions of scroll motifs. These may represent incised variants of several upper Neches River basin regional varieties of Poynor Engraved (see Perttula 2011:Figure 6-65).

Utility wares with incised-punctated decorative elements primarily have oval, rectilinear, and triangular zones filled with tool or fingernail punctates (Table 5; see Figure 11a-d). These appear to be from Maydelle Incised jars (see Suhm and Jelks 1962:Plate 52e), a common upper Neches River basin ceramic ware made and used by Frankston phase Caddo groups. One sherd has a drilled suspension hole (see Figure 11d), indicating it came from a small jar that was suspended in the air; it may have held incense, oils, or pigments.

Table 5. Incised-Punctated decorative elements.

\begin{tabular}{llc}
\hline Decorative element & Rim & Body \\
\hline $\begin{array}{l}\text { oval incised zone filled with tool punctates } \\
\text { oval incised zone filled with tool punctates and adjacent } \\
\text { incised chevron }\end{array}$ & - & 1 \\
rectilinear incised zones filled with tool punctations & 1 & - \\
straight incised line and adjacent tool punctates & - & $2 *$ \\
triangular incised zone filled with fingernail punctates & & 1 \\
$\begin{array}{l}\text { triangular incised zone filled with tool punctates } \\
\text { triangular incised zone filled with tool punctates and adjacent } \\
\text { hatched incised triangles }\end{array}$ & - & 1 \\
\hline Totals & - & 1 \\
\hline
\end{tabular}

*one sherd has drilled suspension hole

Two grog-tempered rim sherds are from La Rue Neck Banded jars (see Suhm and Jelks 1962:Plate 47). These have horizontal neck bands or the crimping of clay neck coils. The one pinched sherd is a body sherd with curvilinear rows of pinched ridges. This sherd is from a Killough Pinched (see Suhm and Jelks 1962:Plate 46) vessel. La Rue Neck Banded and Killough Pinched vessels are common utility wares in Frankston phase ceramic assemblages in the upper Neches River basin.

Utility wares in this sherd assemblage have several different kinds of punctated elements, including fingernail, tool, and circular tool (Table 6). They generally tend to occur in rows on the rim of utility ware jars (see Suhm and Jelks 1962:Plates 79a-b), although one sherd in the collection has randomly placed fingernail punctates covering its exterior vessel surface. 
Table 6. Punctated decorative elements.

\begin{tabular}{lcc}
\hline Decorative element & Rim & Body \\
\hline circular punctated rows & 1 & 4 \\
fingernail punctates, random & 1 & - \\
fingernail punctate, single punctate & 1 & - \\
fingernail punctated rows & - & 6 \\
tool punctated rows & 1 & 8 \\
\hline Totals & 4 & 18 \\
\hline
\end{tabular}

The remainder of the decorated sherds in the TJC collection are from fine wares $(n=67$ sherds, see Table 1); these vessels were decorated after the vessels were leather-hard or after firing, and the vessel surfaces are typically well burnished or polished. These sherds are from vessels decorated with engraved (97 percent) (Table 7), slipped (1.5 percent), and trailed (1.5 percent) decorative elements.

Table 7. Engraved decorative elements.

\begin{tabular}{|c|c|c|}
\hline Decorative element & Rim & Body \\
\hline concentric lines, near-vertical & 2 & - \\
\hline cross-hatched zone & - & 4 \\
\hline cross-hatched and hatched zones & - & 1 \\
\hline curvilinear lines & 1 & 2 \\
\hline curvilinear, circular, and diagonal lines & - & 1 \\
\hline curvilinear and diagonal opposed lines & 1 & 2 \\
\hline diagonal opposed lines & 2 & 3 \\
\hline diagonal lines and curvilinear hatched zone & 1 & - \\
\hline diagonal and curvilinear lines and hatched zone* & - & 1 \\
\hline hatched zone or zones & - & 6 \\
\hline hatched triangle & - & 1 \\
\hline hatched pendant triangles* & - & 1 \\
\hline hatched and cross-hatched triangles & 1 & - \\
\hline horizontal line & 7 & - \\
\hline horizontal and curvilinear lines & 1 & 2 \\
\hline horizontal line and hatched curvilinear zone & - & 1 \\
\hline horizontal line and hatched zone & 2 & - \\
\hline horizontal line with tick marks & - & 1 \\
\hline horizontal and closely-spaced diagonal lines & 1 & - \\
\hline horizontal and diagonal opposed lines & 1 & 3 \\
\hline
\end{tabular}


Table 7. Engraved decorative elements, cont.

\begin{tabular}{lcc}
\hline Decorative element & Rim & Body \\
\hline horizontal and zig-zag lines & 1 & - \\
negative oval and hatched zones & - & - \\
opposed diagonal lines & 1 & 5 \\
parallel lines & - & 1 \\
parallel and curvilinear lines & - & 1 \\
parallel and diagonal opposed lines & - & 6 \\
single straight line & - & 43 \\
\hline Totals & 22 & 4 \\
\hline
\end{tabular}

*bottle sherd

There are a wide variety of engraved decorative elements in the rim and body sherds in the TJC ceramic sherd assemblage (Figures 12a-l and 13a-n; see also Table 7). Most of these fine ware sherds are from defined varieties of Poynor Engraved bowls and carinated bowls (Figures 12e, h and 13e, h-i), the most prevalent Frankston phase fine ware, but several are from Poynor Engraved bottles with hatched zones and triangles (Figure 13c-d, f) (see Suhm and Jelks 1962:Plates 62-63; Perttula 2011:Figures 6-64 and 6-65). Sherds with hatched or cross-hatched zones and triangle elements are quite common in the assemblage, comprising approximately 30 percent of the engraved sherds (see Table 7). Diagonal opposed elements (21 percent of the engraved fine wares) on sherds (see Figures 12f, 1 and 13k) are probably from vessels belonging to various regional varieties of Poynor Engraved, particularly Var. $Q$ (decorated with hatched nested triangles) (Perttula 2011:Figure 6-65).

Engraved sherds with closely spaced curvilinear lines (see Figures 12a, h, j and 13e, h-j, m) may be from Poynor Engraved, var. Cook vessels. These vessels have ovals and circles on rim panels defined by closely-spaced and vertically arcing engraved lines (see Perttula 2011:Figure 6-64c-d). They also may be from the bodies of Poynor Engraved, var. Freeman vessels, as they have scrolls and closely-spaced concentric circles as decorative elements (see Perttula 2011:Figure 6-64i).

One body sherd has a single horizontal engraved line with tick marks on it (see Figure 13a). This is likely from a Patton Engraved, var. Allen carinated bowl. This fine ware type is diagnostic of a post-A.D. 1650 Allen phase Caddo occupation (see Suhm and Jelks 1962:Plate 59; Perttula 2011:Figure 6-66a).

The one fine ware sherd with a trailed decoration is from a grog-tempered vessel, probably a Keno Trailed bottle (see Suhm and Jelks 1962:Plate 44). It has broad curvilinear trailed lines (see Figure 13o). A single grog-tempered body sherd in the TJC sherd collection has a ochre-rich red slip on interior and exterior surfaces; the sherd is probably from a carinated bowl. 


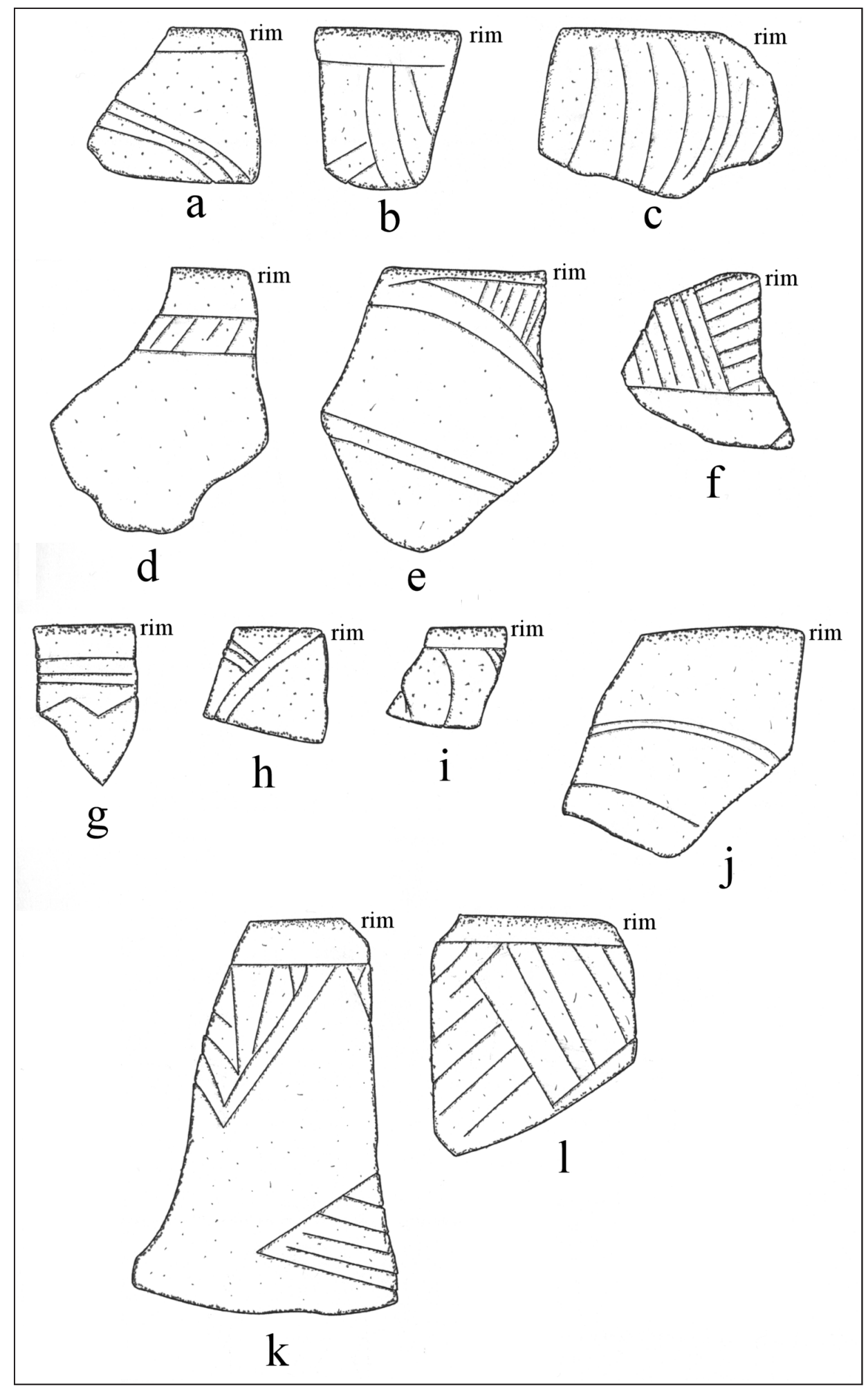

Figure 12. Selected engraved rim sherd decorative elements. 


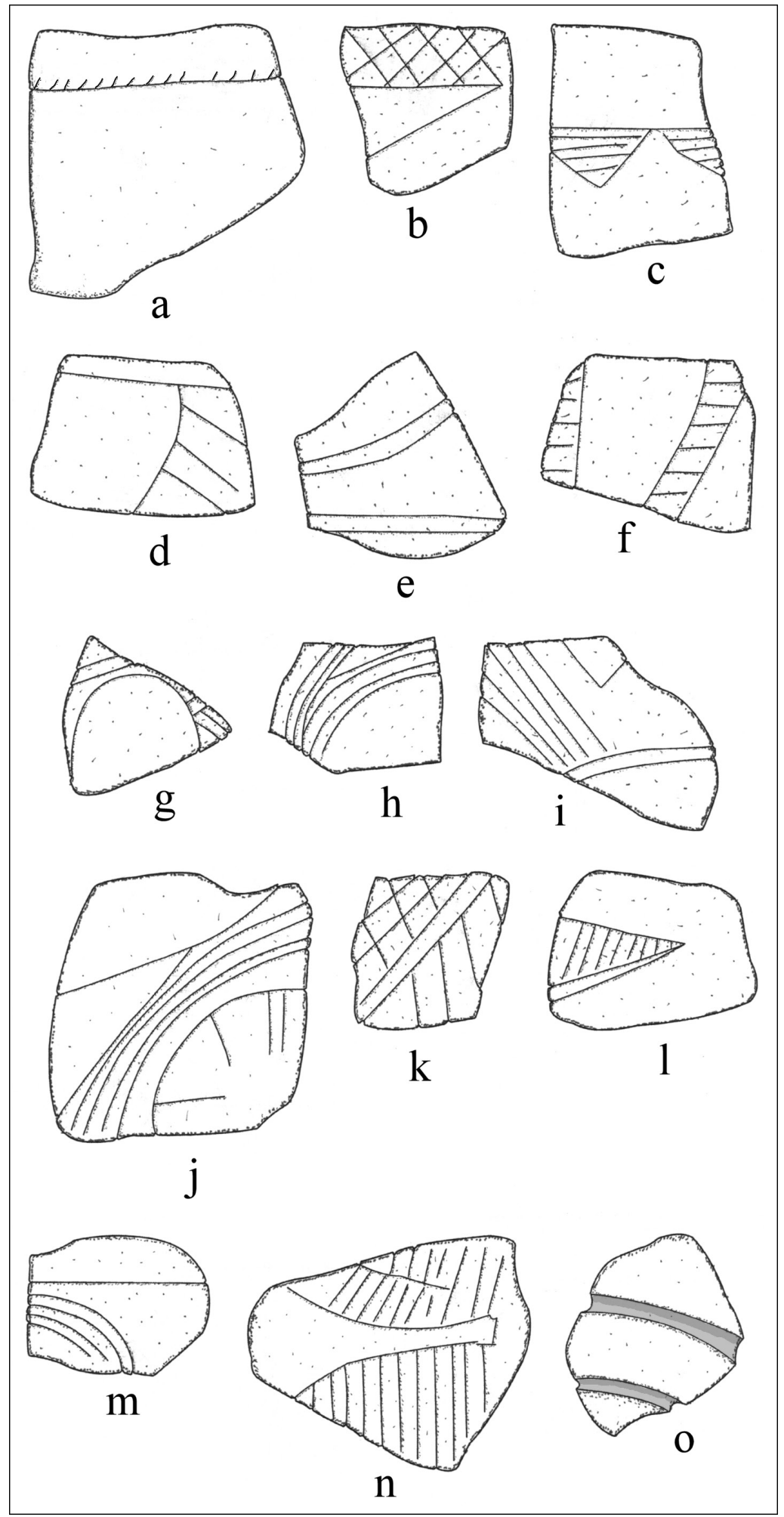

Figure 13. Engraved and trailed body sherd decorative elements: a-n, engraved body; o, trailed body sherd. 


\section{Summary and Conclusions}

The decorative styles of the Caddo ceramic vessels in the Tyler Junior College collection are consistent with vessels made and used after ca. A.D. 1400 by East Texas Caddo groups. Identified fine wares include a cf. Simms Engraved, var. Darco bowl, a type seen on late 17th century Caddo sites in the Sabine River basin in Harrison County and in other locales across East Texas (see Perttula 2013; Perttula et al. 2014), and a Simms Engraved carinated bowl. The utility wares include a Bullard Brushed jar, Killough Pinched jars ( $n=2)$, a Harleton Appliqued jar, a La Rue Neck Banded jar, as well as unidentified appliqued and brushed-incised and brushed-incised jars. These utility wares are found in both Frankston phase (ca. A.D. 1400-1650) and Titus phase (ca. A.D. 1430-1680) cemetery assemblages in the Neches, Sabine, and Big Cypress drainage basins in East Texas.

Based on the decorative elements identified in the utility wares and fine ware sherds, and the almost exclusive use of grog temper in vessel manufacture, the large ceramic sherd assemblage may be from one or more Caddo domestic occupations in the upper Neches River basin that span a longer period of time, from as early as ca. A.D. 1400 to as late as the late 17 th to early 18 th century, during the Frankston phase and the Allen phase. Certainly the common occurrence of sherds from several varieties of Poynor Engraved would support such a temporal and cultural affiliation, as would the presence of utility ware sherds of the types Bullard Brushed, Killough Pinched, La Rue Neck Banded, and Maydelle Incised. 


\section{References Cited}

Perttula, T. K.

2011 The Ceramic Artifacts from the Lang Pasture Site (41AN38) and the Place of the Site within an Upper Neches River Basin Caddo Ceramic Tradition. In Archeological Investigations at the Lang Pasture Site (41AN38) in the Upper Neches River Basin of East Texas, assembled and edited by T. K. Perttula, D. B. Kelley, and R. A. Ricklis, pp. 145-320. Archeological Studies Program Report No. 129. Texas Department of Transportation, Environmental Affairs Division, Austin.

2013 Caddo Ceramics in East Texas. Bulletin of the Texas Archeological Society 84:181-212.

2014 The Horton Site (41CP16) on Big Cypress Creek in the East Texas Pineywoods. Journal of Northeast Texas Archaeology 43:27-43.

Perttula, T. K. and B. Nelson

2013 Two Middle Caddo Period Habitation Sites and Cemeteries in the Sabine River Basin, Gregg County, Texas. Special Publication No. 27. Friends of Northeast Texas Archaeology, Pittsburg and Austin.

Perttula, T. K. and M. Thacker

2014 Analysis of New Artifact Collections from Archaic to Ancestral Caddo Sites in the Saline Creek Basin in Northern Smith County, Texas. Journal of Northeast Texas Archaeology 43:1-25.

Perttula, T. K., P. S. Marceaux, and B. Nelson

2012a Study of the Margaret Hinton Collection of Pottery Vessels from Northeast Texas Caddo Cemeteries. Special Publication No. 24. Friends of Northeast Texas Archaeology, Austin and Pittsburg.

Perttula, T. K., B. Nelson, and R. Z. Selden, Jr.

2013 Documentation of Cemeteries and Funerary Offerings from Sites in the Upper Neches River Basin, Anderson, Cherokee, and Smith Counties, Texas. Special Publication No. 26. Friends of Northeast Texas Archaeology, Pittsburg and Austin.

Perttula, T. K., B. Nelson, and M. Walters

2012b Caddo Archaeology at the Henry Spencer Site (41UR315) in the Little Cypress Creek Basin of East Texas. Special Publication No. 20. Friends of Northeast Texas Archaeology, Pittsburg and Austin.

Perttula, T. K., R. Z. Selden, Jr., and B. Nelson

2014 A Catalog of Selected Caddo Ceramic Vessels in the Buddy Jones Collection at the Gregg County Historical Museum. Special Publication No. 30. Friends of Northeast Texas Archaeology, Pittsburg and Austin.

Perttula, T. K., M. Walters, and B. Nelson

2009a Documentation of the Native American Ceramic Vessels from Northeast Texas, Southern Arkansas, and Eastern Oklahoma in the Boyce Smith Museum in Troup, Texas. Special Publication No. 8. Friends of Northeast Texas Archaeology, Pittsburg and Austin.

2010a Caddo Pottery Vessels and Pipes from Sites in the Big Cypress, Sulphur, Neches-Angelina, and Middle Sabine River Basins in the Turner and Johns Collections, Camp, Cass, Cherokee, Harrison, Morris, Titus, and Upshur Counties, Texas and Sabine Parish, Louisiana. Special Publication No. 10. Friends of Northeast Texas Archaeology, Pittsburg and Austin. 
2010b Caddo Pottery Vessels and Pipes from the Johns Site (41CP12) in the Big Cypress Creek Basin in the Turner and Johns Collections, Camp County, Texas. Special Publication No. 11. Friends of Northeast Texas Archaeology, Austin and Pittsburg.

2012c Little Cypress Creek Basin Archaeology: Six Late Caddo Period Cemeteries in Upshur County, Texas. Special Publication No. 22. Friends of Northeast Texas Archaeology, Austin and Pittsburg.

Perttula, T. K., M. Walters, S. Marceaux, and B. Nelson

2009b Caddo Pottery Vessels and Pipes from Sites in the Middle and Upper Sabine and Upper Neches River Basins, Smith and Wood Counties, Texas. Special Publication No. 7. Friends of Northeast Texas Archaeology, Pittsburg and Austin.

Perttula, T. K., M. Walters, R. Cast, B. Gonzalez, and B. Nelson

2007 Documentation of Funerary Offerings from a Prehistoric Caddo Burial at Site 41WD244, Wood County, Texas. Caddo Nation of Oklahoma and Archeological \& Environmental Consultants, LLC, Binger and Austin.

Perttula, T. K., M. Walters, B. Nelson, B. Gonzalez, and R. Cast, with a contribution by R. G. Franciscus 2010c Documentation of Associated and Unassociated Caddo Funerary Objects in the Stephen F. Austin State University Collections, Nacogdoches, Texas. Stephen F. Austin State University Press, Nacogdoches.

Suhm, D. A. and E. B. Jelks (editors)

1962 Handbook of Texas Archeology: Type Descriptions. Special Publication No. 1, Texas Archeological Society, and Bulletin No. 4, Texas Memorial Museum, Austin. Reprinted in 2009, Gustav's Library, Davenport, Iowa. 